Vol II. No. 2, Maret 2018, hlm. 180 - 187

Available online at www.jurnal.una.ac.id/indeks/jmp

\title{
PENGARUH PENDEKATAN REALISTIC MATHEMATICS EDUCATION (RME) TERHADAP KEMAMPUAN PENALARAN MATEMATIKA SISWA SMKS-PP STABAT
}

\author{
Lilis Saputri \\ STKIP Budidaya Binjai \\ e-mail: falinsyah@yahoo.com
}

\begin{abstract}
The purpose of the research is determined the effect of Realistic Mathematics Education (RME) approach to students' math competency. The research is a quasi-experimental research, with pretest and posttest control group design. Population in this research is all students of class XI SMKSPertanian Pembangunan Putra Jaya Stabat, and sample in this research consists of two classes. Sample in experiment group was 35 students, and control group samples were 35 students. Data in this study were analyzed using simple regression test. Average of math experimental reasoning skills before and after learning was 68.43 and 76.43. Testing the hypothesis in this study using the r-test, after calculations obtained value $r$ _hitung students' math reasoning ability of experimental class is 0.730 while the value of $r_{-}$tabel is 0.334 . So it can be concluded that there is influence of Realistic Mathematics Education (RME) approach to students' mathematical reasoning ability on trigonometry at XI class SMKS-Pertanian Pembangunan Putra Jaya Stabat 2016/2017.
\end{abstract}

Keywords: Realistic Mathematics Education Approach (RME), Ability Mathematical Reasoning

\begin{abstract}
Abstrak
Tujuan penelitian ini adalah untuk mengetahui pengaruh pendekatan Realistic Mathematics Education (RME) terhadap kemampuan penalaran matematika siswa. Penelitian ini merupakan penelitian eksperimen semu, dengan desain penelitian pretest and postest control group design. Populasi dalam penelitian ini adalah seluruh siswa kelas XI SMKS-Pertanian Pembangunan Putra Jaya Stabat, sedangkan sampel dalam penelitian ini terdiri dari dua kelas. Sampel pada kelompok eksperimen berjumlah 35 orang, dan sampel pada kelompok kontrol juga berjumlah 35 orang. Data dalam penelitian ini dianalisis menggunakan uji regresi sederhana. Rata-rata tes kemampuan penalaran matematika kelas ekperimen sebelum dan sesudah pembelajaran adalah 68,43 dan 76,43. Pengujian hipotesis dalam penelitian ini menggunakan uji-r, setelah dilakukan perhitungan diperoleh nilai $r_{\text {hitung }}$ kemampuan penalaran matematika siswa kelas eksperimen adalah 0,730 sedangkan nilai $r_{\text {tabel }}$ adalah 0,334. Maka dapat disimpulkan bahwa terdapat pengaruh pendekatan Realistic Mathematics Education $(R M E)$ terhadap kemampuan penalaran matematika siswa pada materi trigonometri kelas XI SMKS-Pertanian Pembangunan Putra Jaya Stabat Tahun Pelajaran 2016/2017.
\end{abstract}

Kata Kunci : Pendekatan Realistic Mathematics Education (RME), Kemampuan Penalaran Matematika 
Vol II. No. 2, Maret 2018, hlm. 180 - 187

Available online at www.jurnal.una.ac.id/indeks/jmp

Pendidikan merupakan faktor utama dalam pembentukan pribadi manusia, secara umum pendidikan memiliki arti sebagai suatu proses usaha dalam mengembangkan diri setiap individu untuk dapat hidup dan melangsungkan kehidupan, sehingga menjadi seorang yang terdidik. Salah satu ilmu pendidikanyang dipelajari adalah matematika. Matematika merupakan ilmu yang banyak dimanfaatkan oleh banyak ilmu pengetahuan, sebagai ilmu yang banyak dimanfaatkan pada hampir semua pengetahuan matematika mempunyai peranan penting dalamupaya penguasaan ilmu pengetahuan dan teknologi. Menyadari akan pentingnya matematika, maka belajar matematika seharusnya dapat dijadikan sebagai suatu kegiatan yang menyenangkan.

Salah satu tujuan pembelajaran matematika di Sekolah Menengah Pertama berdasarkan Peraturan Pemerintah No. 22 tahun 2006 dalam KTSP adalah : siswa mampu menggunakan penalaran pada pola dan sifat, melakukan menipulasi matematika dalam membuat gene-ralisasi, menyusun bukti, atau menjelaskan gagasan dan pernyataan matematika. Mulis, et al. (dalam Widyasari) mengungkapkan : terdapat tiga ranah kognitif matematika, yakni knowing(pengetahuan), applying (penerapan), dan reasoning (penalaran).

Kondisi pendidikan di Indonesia terutama matematika dinilai sangat rendah. Trends In International Mathematics and Science Study (TIMSS) tahun 2011 menunjukkan : peringkat matematika Indonesia berada di posisi 36 dari 40 negara, sedangkan hasil penelitian Programme of
International Student Assessment (PISA) tahun 2012 menunjukkan bahwa : Indonesia menempati peringkat 64 dari 65 negara yang berpartisipasi. Hal ini sejalan dengan penelitian awal yang dilakukan di sekolah SMKS-Pertanian Pembangunan Putra Jaya Stabat. Salah sau soalnya adalah sebagai berikut :

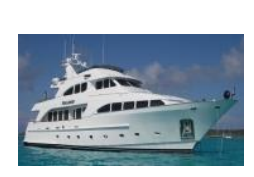

Dua buah kapal berlayar bersama-sama daripelabuhan.Kapal A berlayar sejauh 20 kmdengan arah

$150^{\circ}$, sedangkan kapal Bberlayar sejauh $21 \mathrm{~km}$ dengan arah $240^{\circ}$. Buatlah sketsa gambar darimasalah ini!Benarkah sudut yang terbentuk di kapal Alebih besar dari sudut yang terbentuk di kapal B? Jelaskan!

\section{Gambar 1. Tes Penalaran Awal}

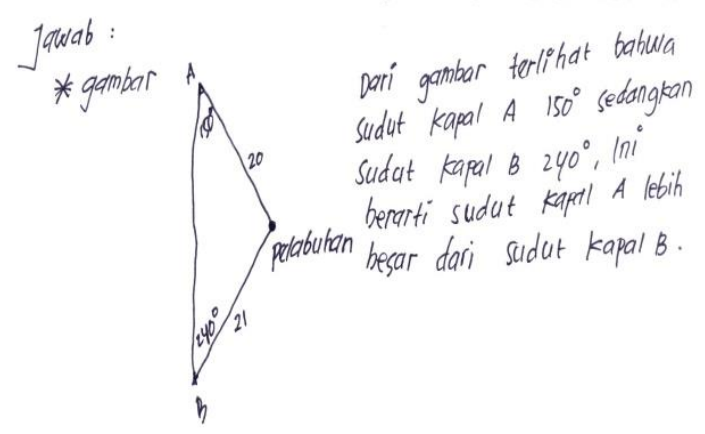

\section{Gambar 2. Salah Satu Jawaban Siswa}

Dari hasil analisis tes kemampuan penalaran pada materi trigonometri yang diberikan kepada 29 siswa terdapat 18 siswa menunjukkan tingkat penalaran yang rendah, dan 11 orang siswa memiliki kemampuan penalaran yang cukup. Setelah dianalisis terlihat bahwa kemampuan penalaran matematika siswa masih rendah, dalam 
Vol II. No. 2, Maret 2018, hlm. 180 - 187

Available online at www.jurnal.una.ac.id/indeks/jmp

kategori belum mengerti atau pencapaian rendah dikarenakan kurangnya pemahaman konsep dari siswa tersebut.Salah satu penyebab yang mengakibatkan kemampuan penalaran matematika siswa rendah dikarenakan banyak siswa yang menganggap matematika itu sulit dipelajari dan karakteristik matematika yang bersifat abstrak sehingga siswa menganggap matematika merupakan momok yang menakutkan. Abdurrahman (dalam Nurdalilah, dkk.) juga mengatakan bahwadari berbagai bidang studi yang diajarkan di sekolah, matematika merupakan bidang studi yang dianggap paling sulit oleh para siswa, baik yang tidak berkesulitan belajar dan lebih-lebih bagi siswa yang berkesulitan belajar.

Kemampuan penalaran matematika merupakan suatu proses berpikir, yang mencakup berpikir dasar, berpikir kritis, dan berpikir kreatif, tetapi tidak termasuk mengingat (recall).Ball, Lewis \& Thamel(dalam Widjaya) yang menyatakanbahwa penalaran matematika adalah fondasi untuk mendapatkan atau mengkonstruk pengetahuan matematika. Adapun kemampuan penalaran matematika yang harus dicapai siswa berdasarkan Peraturan Dirjen Dikdasmen No.506/C/PP/2004 (dalam Utami, dkk.) adalah sebagai berikut :

(1)Kemampuan menyajikan pernyataan matematika secara lisan, tertulis, gambar dan diagram. (2) Kemampuan mengajukan dugaan. (3) Kemampuan melakukan manipulasi matematika. (4) Kemampuan menyusun bukti, memberikan alasan /bukti terhadap kebenaran solusi. (5) Kemamapuan menarik kesimpulan dari pernyataan. (6) Memeriksa kesahihan suatu argument. (7) Menemukan pola atau sifat dari gejala matematis untuk membuat generalisasi.

Mengingat akan pentingnya kemampuan penalaran matematika dalam pembelajaran, maka setiap siswa harus memiliki kemampuan penalaran untuk memecahkan masalah matematika tidak terkecuali siswa sekolah menengah. Namun, fakta sesungguhnya dilapangan menun-jukkan kemampuan penalaran matematika siswa masih rendah. Salah satu kecenderungan yang menyebabkan sejumlah siswa gagal dalam menguasai pokok bahasan matematika karena siswa tersebut kurang menggunakan nalar yang logis dalam menyelesaikan soal yang diberikan. Pada umunya siswa di Indonesia lebih banyak mengerjakan soal yang diekspresikan dalam bahasa dan simbol matematika yang dibuat dalam konteks yang jauh dari realitas kehidupan sehari-hari. Akibatnya, siswa menganggap matematika sebagai pelajaran yang tidak menyenangkan. Mereka pun tidak mampu menerapkan teori di sekolah untuk memecahkan masalah seharihari.

Dengan menggunakan contoh kasus yang terjadi dalam kehidupan sehari-hari diharapkan muncul kesadaran siswa akan pentingnya matematika dalam realitas kehidupan. Materi trigonometri merupakan suatu materi yang bersifat abstrak dan memerlukan kemampuan penalaran yang logis dalam menyelesaikan masalah-masalahnya, selain itu materi ini juga memiliki keterkaitan dengan realitas kehidupan sehari-hari yang dialami siswa.

Penggunaan pendekatan Realistic Mathematics Education (RME) merupakan salah satu alternatif untuk 
Vol II. No. 2, Maret 2018, hlm. 180 - 187

Available online at www.jurnal.una.ac.id/indeks/jmp

dapat meningkatkan kemampuan penalaran matematika siswa. Hal ini sejalan dengan pendapat yang diungkapakan oleh Usdiyana, dkk., yang menyatakan bahwa pembelajaran matematika dengan pendekatan matematika realistik pada dasarnya cukup membantu siswa untuk meningkatkan kemampuan berpikir logis. Pada umumnya siswa merasa senang, tertarik, dan mudah mengerti belajar matematika dengan pendekatan matematika realistik, terutama siswa kelompok sedang dan rendah

Pendekatan Realistic Mathematics Education (RME) merupakan suatu pendekatan yang menempatkan realitas dan pengalaman siswa sebagai titik awal pembelajaran dimana siswa diberi kesempatan untuk mengkonstruksi sendiri pengetahuan matematika formalnya melalui masalah-masalah realitas yang ada. Fruedenthal (dalam Shoimin) menyatakan matematika harus dikaitkan dengan realita dan matematika merupakan aktivitas manusia.

Berdasarkan penjelasan di atas peneliti merasa perlu melakukan penelitian tentang pengaruh pendekatan Realistic Mathematics Education (RME) terhadap kemampuan penalaran matematika siswa pada materi trigonometri kelas XI SMKS-Pertanian Pembangunan Putra Jaya Stabat Tahun Pelajaran 2016/2017. Adapun rumusan masalah dalam penelitian ini adalah apakah terdapat pengaruh pendekatan Realistic Mathematics Education $(R M E)$ terhadap kemampuan penalaran matematika siswa pada materi trigonometri kelas XI SMKS-Pertanian Pembangunan Putra Jaya Stabat Tahun Pelajaran 2016/2017?. Sedangkan tujuan dalam penelitian ini yaitu untuk mengetahui pengaruh pendekatan
Realistic Mathematics Education $(R M E)$ terhadap kemampuan penalaran matematika siswa pada materi trigonometri kelas XI SMKS-Pertanian Pembangunan Putra Jaya Stabat Tahun Pelajaran 2016/2017.

\section{METODE}

Jenis penelitian ini adalah penelitian eksperimen semu. Populasi dalam penelitian ini adalah seluruh siswa kelas XI SMKS-Pertanian Pembangunan Putra Jaya Stabat Tahun Pelajaran 2016/2017 yang berjumlah 152 orang yang terdiri dari 4 kelas. Sampel dalam penelitian ini diambil dengan cara simple random sampling, yaitu pengambilan anggota sampel secara acak. Dari hasil pengambilan sampel terpilihlah dua kelas sebagai sampel dalam penelitian ini. Kedua kelas tersebut adalah kelas XIPeternakan $^{\mathrm{B}}$ yang berjumlah 35 orang sebagai kelas kontrol, dan kelas XIPerkebunan $^{B}$ yang berjumlah 35 orang sebagai kelas eksperimen.

Desain yang digunakan dalam penelitian ini adalah pretest and posttest control group desaign. Adapun pola dalam desain ini adalah

\begin{tabular}{|c|c|c|}
\hline$E$ & $\begin{array}{ll}0_{1} \quad X \\
\end{array}$ & $\mathrm{O}_{2}$ \\
\hline K & $0_{1}$ & $\mathrm{O}_{2}$ \\
\hline
\end{tabular}

E : kelompok eksperimen

$\mathrm{K}$ : kelompok kontrol

$\mathrm{X}$ : pendekatan Realistic

Mathematics Education (RME)

Teknik pengumpulan data dalam penelitian ini menggunakan observasi dan tes kemampuan penalaran matematika siswa. Tes yang digunakan terbagi menjadi dua, yaitu tes awal (pretest) untuk mengetahui kemam-puan penalaran matematika 
Vol II. No. 2, Maret 2018, hlm. 180 - 187

Available online at www.jurnal.una.ac.id/indeks/jmp

siswa sebelum proses pembelajaran dan tes akhir (post-test) untuk mengetahui kemampuan penalaran matematika siswa setelah dilakukan proses pembelajaran.

\section{HASIL DAN PEMBAHASAN}

Proses pembelajaran dilakukan pada kedua kelas. Kelas eksperimen menggunakan pendekatan RealisticMathematics Education (RME) dan Lembar Aktivitas Siswa (LAS), sedangkan pada kelas kontrol, proses pembelajaran menggunakan strategi pembelajaran inkuiri. Hasil penelitian ini diambil dari nilai pretest dan nilai post-test kemampuan penalaranmatematika siswa. Nilai ratarata pretest siswa kelas eksperimen adalah 68,43 dan nilai rata-rata posttest siswa kelas kontrol adalah 69,28. Sedangkan nilai rata-rata post-test siswa kelas eksperimen adalah 78,43 dan nilai rata-rata kelas kontrol adalah 70,86 .Secara visual hasil tes kemampuan penalaran matematika siswa sebelum dan sesudah pembelajaran dapat dilihat pada grafik berikut :

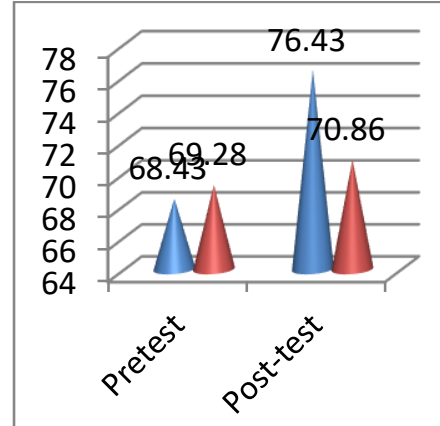

\section{Gambar 3. Hasil Tes Kemampuan PenalaranMatematika}

Dengan demikian dapat dilihat bahwa terdapat peningkatan yang signifikan pada kelas eksperimen antara sebelum dan sesudah proses pembelajaran.

Untuk mendeskripsikan tentang pencapaian nilai siswa pada kelas eksperimen, yaitu kelas yang mendapatkan perlakuan pembelajaran dengan menggunakan pendekatan Realistic Mathematics Education $(R M E)$ berdasarkan hasil pretest dan post-test yang telah dikerjakan, maka dilakukan perhitungan dengan menggunakan uji analisisregresi sederhana. Uji ini dilakukan untuk melihat seberapa besar pengaruh pendekatanRealistic Mathematics Education (RME) terhadap kemampuan penalaran matematika siswa.Hasil analisis regresi yang telah dilakukan adalah seperti tampak pada tabel berikut ini :

Tabel 1. Hasil Analisis Varians Untuk

$$
\text { Regresi Linier }
$$

\begin{tabular}{ccc}
\multicolumn{3}{c}{$\widehat{\boldsymbol{Y}}=\mathbf{9}, \mathbf{5 6}+\mathbf{0}, \mathbf{9 8} \boldsymbol{X}$} \\
\hline Sumber & Dk JKT & F
\end{tabular}

Varians

\begin{tabular}{lll}
\hline Tota; & 35 & 37,87
\end{tabular}

\begin{tabular}{lll}
\hline koef (a) & 1 & 204446,43 \\
\hline Koef & 1 & 2526,9986
\end{tabular}

(a|b)

\begin{tabular}{llll} 
Sisa (S) & 33 & 66,73 & \\
$\begin{array}{lll}\text { Tuna } \\
\text { Cocok }\end{array}$ & 6 & 79,96 & 1,25 \\
(TC) & & & \\
\cline { 1 - 2 } Galat (G) & 27 & 63,81 & \\
\hline
\end{tabular}

Kelas Kontrc

Setelah analisis varians untuk regresi diketahui, selanjutnya dilakukan uji keberartian. Uji ini dilakukan untuk mengetahui apakah hubungan variabel bebas dengan variabel terikat berarti signifikan atau tidak. Hasil dari uji keberartian adalah sebagai berikut : 


\section{Jurnal}

MATEMATICS PAEDAGOGIC

Vol II. No. 2, Maret 2018, hlm. 180 - 187

Available online at www.jurnal.una.ac.id/indeks/jmp

Tabel 2. Hasil Uji Keberartian

\begin{tabular}{ccccl}
\hline $\mathbf{F}_{\text {hitung }}$ & $\begin{array}{l}\mathbf{F}_{\text {tabel }} \\
\mathbf{\alpha =} \\
\mathbf{5 \%}\end{array}$ & $\begin{array}{c}\mathbf{d k} \\
\text { pembila } \\
\text { ng }\end{array}$ & $\begin{array}{c}\text { dk } \\
\text { penyeb } \\
\text { ut }\end{array}$ & $\begin{array}{l}\text { Keterang } \\
\text { an }\end{array}$ \\
\hline 37,8 & 4,14 & 1 & 33 & $\begin{array}{l}\text { Koefisien } \\
\text { arah } \\
\text { regresi } \\
\text { berarti } \\
(b \neq 0)\end{array}$ \\
& & & & \\
& & & \\
\hline
\end{tabular}

Dari hasil dari perhitungan tersebut diperoleh nilai $F_{\text {hitung }}=$ 37,87 , sedangkan harga $F_{\text {tabel }}(1,33)=$ 4,14untuk taraf signifikan 5\%. Dengan demikian harga $F_{\text {hitung }}>F_{\text {tabel }}$ berarti Ho ditolak dan Ha diterima, dengan demikian dapat disimpulkan bahwa koefisien arah regresi berarti $(b \neq 0)$.

Setelah koefisien arah regresi berarti maka selanjutnya dilakukan uji linieritas, dengan tujuan untuk mengetahui apakah dua variabel mempunyaihubungan yang linear atau tidak secara signifikan. Hasil uji linieritas adalah :

Tabel 3. Hasil Uji Linieritas

\begin{tabular}{ccccl}
\hline $\mathbf{F}_{\text {hitung }}$ & $\begin{array}{c}\mathbf{F}_{\text {tabel }} \\
\mathbf{\alpha =} \\
\mathbf{5 \%}\end{array}$ & $\begin{array}{c}\mathbf{d k} \\
\text { pemb } \\
\text { ilang }\end{array}$ & $\begin{array}{c}\mathbf{d k} \\
\text { penyeb } \\
\mathbf{u t}\end{array}$ & $\begin{array}{l}\text { Ketera } \\
\text { ngan }\end{array}$ \\
\hline 1,25 & 2,46 & 6 & 27 & $\begin{array}{l}\text { Regresi } \\
\text { linier }\end{array}$ \\
\hline
\end{tabular}

Hasil dari perhitungan tersebut diperoleh nilai $F_{\text {hitung }}=1,25$, sedangkan harga $F_{\text {tabel }}(6,27)=$ 2,46untuk taraf signifikan 5\%. Dengan demikian harga $F_{\text {hitung }}<F_{\text {tabel }}$ berarti Ho diterima dan $\mathrm{Ha}$ ditolak, dengan demikian kesimpulannya adalah regresi linier.Secara visual hasiluji linieritas soal pretest dan post-testdapat dilihat pada gambar berikut :

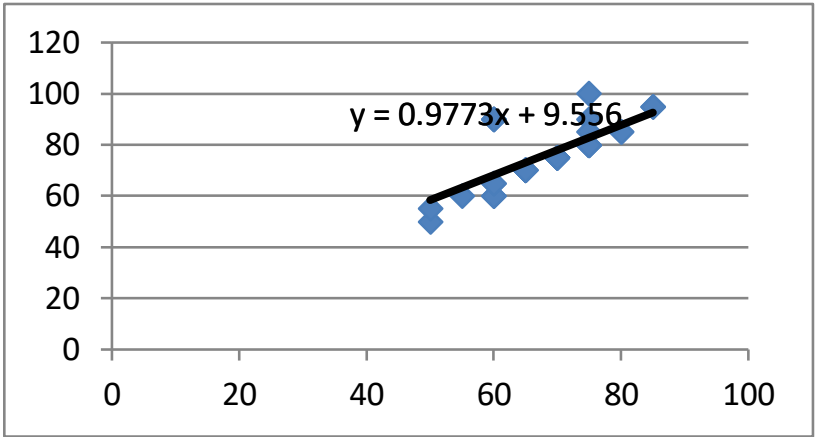

\section{Gambar 4. Hasil Uji Linieritas}

Hasil uji linieritas pada kelas eksperimen yang diajar dengan pendekatan Realistic Mathematics Eucation (RME)membentuk grafik garis lurus. Ini berarti hasil perhitungan nilai pretest dan post-test siswa membentuk regresi yang linier.

Setelah data yang diketahui berarti dan linier, selanjutnya dilakukan pengujian terhadap hipotesis. Perhitungan uji hipotesis dilakukan untuk mengetahui ada atau tidaknya pengaruh dalam pembelajaran dengan menggunakan pendekatan Realistic Mathematics Education (RME) terhadap kemampuan penalaran matematika siswa. Pengujian hipotesis dalam penelitian ini menggunakan uji-r dengan menggunakan data hasil kemampuan penalaran matematika yang diperoleh siswa, yaitu data hasil pretest dan data hasil post-test. Hasil perhitungan dengan menggunakan uji-r dapat dilihat pada tabel berikut :

Tabel 4. Hasil Uji Hipotesis

\begin{tabular}{cccl}
\hline $\mathbf{r}_{\text {hitung }}$ & $\begin{array}{c}\mathbf{r}_{\text {tabel }} \\
\boldsymbol{\alpha = 5 \%}\end{array}$ & $\mathbf{N}$ & \multicolumn{1}{c}{ Keterangan } \\
\hline 0,730 & 0,334 & 35 & Terdapat pengaruh antara \\
& & & pendekatan Realistic \\
& & Mathematics Education \\
& & $($ RME) dan kemampuan \\
& & penalaran matematika \\
& & siswa \\
& & $(\mathrm{r} \neq 0)$ \\
& & \\
& &
\end{tabular}


Vol II. No. 2, Maret 2018, hlm. 180 - 187

Available online at www.jurnal.una.ac.id/indeks/jmp

Setelah perhitungan dengan menggunakan uji-r dilakukan, maka diperoleh nilai $r_{\text {hitung }}=0,730$. Kemudian nilai tersebut dibandingkan dengan nilai $r_{\text {tabel }}$ dengan $\mathrm{n}=35$ dan taraf signifikan $5 \%=0,334$. Karena harga $r_{\text {hitung }}>r_{\text {tabel }}$ maka Ho ditolak dan $\mathrm{Ha}$ diterima, dengan demikian dapat disimpulkan terdapat pengaruh antara pendekatan Realistic Mathematics Education (RME) dan kemampuan penalaran matematika siswa.

\section{Pembahasan}

Proses pembelajaran dengan menggunakan pendekatan Realistic Mathematics Education (RME) menjadikan siswa lebih mampu berpartisipasi dalam pembelajaran, siswa menjadi lebih aktif, siswa menjadi lebih bertanggung jawab terhadap kelompoknya, siswa menjadi lebih tahu inti dari pembelajaran yang mereka lakukan dengan adanya kesimpulan, siswa menjadi lebih mampu dalam menyelesaikan masalahmasalah yang berkaitan dengan materi, serta kesan senang dalam pembelajaran lebih terlihat. Sedangkan pembelajaran dengan menggunakan starategi pembelajaran inkuiri menjadikan siswa kurang aktif, banyak siswa yang menunjukkan sikap bosan karena harus mengerjakan soal-soal sendiri, terlebih lagi bagi siswa yang memiliki kemampuan rendah.

Uji regresi yang dilakukan terhadap hasil pretest dan post-test pada kelas eksperimen menunjukkan adanya perbedaan hasil yang cukup signifikan antara sebelum dan sesudah diberikan perlakuan.Hasil nilai $r_{\text {hitung }}=0,730$, hasil nilai $r_{\text {tabel }}=$ 0,334. Karena $r_{\text {hitung }}>r_{\text {tabel }}$ maka Ho ditolak dan $\mathrm{Ha}$ diterima. Dengan demikian dapat ditarik kesimpulan bahwa kemampuan penalaran matematika siswa sesudah diberikan perlakuan lebih baik daripada sebelum diberikan perlakuan. Dengan kata lain terdapat terdapat pengaruh antara pendekatan Realistic Mathematics Education (RME) dan kemampuan penalaran matematika siswa.

\section{SIMPULAN \\ Kesimpulan}

Setelah dilaksanakannya penelitian serta berdasarkan analisis data dan pengujian hipotesis dapat diambil kesimpulan bahwa terdapat pengaruh pendekatan Realistic Mathematics Education (RME) terhadap kemampuan penalaran matematika siswa pada materi trigonometri kelas XI SMKSPertanian Pembangunan Putra Jaya Stabat Tahun Pelajaran 2016/2017. Berdasarkan hasil perhitungan yang dilakukan diperoleh hasil nilai $\mathrm{r}_{\text {hitung }}=0,730 \quad$ sedangkan nilai $r_{\text {tabel }}=0,334$. Karena $\mathbf{r}_{\text {hitung }}>\mathbf{r}_{\text {tabel }}$ maka Ho ditolak dan $\mathrm{Ha}$ diterima, dengan demikian dapat ditarik kesimpulan bahwa terdapat terdapat pengaruh antara pendekatan Realistic Mathematics Education (RME) dan kemampuan penalaran matematika siswa. Hal ini dikarenakan pelaksanaan pembelajaran matematika dengan pendekatan Realistic Mathematics Education (RME) dapat meningkatkan aktivitas dan kreatifitas berpikir siswa, karena dalam pendekatan ini soal yang diberikan dikaitkan dengan kehidupan senari-hari yang dialami siswa, sehingga membuat siswa lebih tertarik untuk mengerjakan soal. Selain itu cara pengerjaannya juga dibuat dalam kelompok diskusi, ini membuat siswa lebih senang mengerjakan soal, karena mereka tidak harus mengerjakannya sendiri, terlebih lagi pada akhir diskusi 
Vol II. No. 2, Maret 2018, hlm. 180 - 187

Available online at www.jurnal.una.ac.id/indeks/jmp

siswa diberi kesempatan untuk memaparkan hasil pekerjaannya, sehingga membuat siswa untuk berani berbicara di depan kelas.

\section{Saran}

Dengan memperhatikan hasil penelitian dan pembahasan, peneliti memberikan saran sebagai berikut:

1. Bagi siswa, diharapkan siswa secara aktif dalam membangun pengetahuan, dan meningkatkan kemampuan penalaran matematikanya serta memperoleh pengalaman baru dan belajar lebih bermakna.

2. Bagi guru, dapat menjadi salah satu acuan dalam penggunaan pendekatan pembelajaran yang bervariasi dalam mengejar dikelas.

\section{DAFTAR RUJUKKAN}

Nurdalilah. Syahputra, Edi. Armanto, Dian. Perbedaan Kemampuan Penalaran Matematika dan Pemecahan Masalah pada Pembelajaran Berbasis Masalah dan Pembelajaran Konvensional di SMA Negeri 1 Kualuh Selatan. Jurnal Pendidikan Matematika PARADIKMA.

Permendiknas. Standar Isi Mata Pelajaran Matematika. Jakarta : 2006.

Shoimin, Aris. 68 Model Pembelajaran Inovatif dalam Kurikulum 2013. Yogyakarta : Ar-ruzz. 2014.

Usdiyana, Dian. Purniati, Tia. Yulianti, Kartika. Harningsih, Eha. Meningkatkan Kemampuan Berpikir Logis Siswa SMP Melalui Pembelajaran Matematika Realistik. Jurnal Pendidikan Matematika. 2009.
3. Bagi peneliti, produk ini dapat dijadikan sebagai bahan masukan dan bandingan dalam pengembangan penelitian selanjutnya terkait penerapan paradigma baru pembelajaran disekolah.

4. Bagi sekolah, memberikan masukan dan pertimbangan untuk meningkatkan kualitas pem-belajaran di sekolah khususnya dalam pemilihan pendekatan pembelajaran.

5. Bagi lembaga pendidikan, memberikan saran bagi pemerintah dalam upaya meningkatkan kualitas pendidikan melalui pendekatan pembelajaran tertentu dalam proses belajar mengajar.

Utami, Nita Putri. Mukhni. Jazwinarti. Kemampuan Penalaran Matematis Siswa Kelas XI IPA SMAN 2 Painan Melalui Penerapan Pembelajaran Think Pair Square. Jurnal Pendidikan Matematika. 2014.

Widjaya, Wanti. Design Realistic Mathematics Education Lesson. Makalah Seminar Nasional Pendidikan, Program Pascasarjana Universitas Sriwijaya, Palembang, 2010.

Widyasari, Nurbaiti. Meningkatkan Kemampuan Penalaran dan Disposisi Matematis Siswa SMP Melalui Pendekatan Metaphorical Thinking. Tesis. Universitas Pendidikan Indonesia. 2013 